Available online at http://jurnal.goretanpena.com/index.php/JSSR

\title{
PENGARUH LOKASI, KELENGKAPAN PRODUK, DAN PELAYANAN TERHADAP KEPUTUSAN PEMBELIAN KONSUMEN PADA IMAM MARKET KISARAN
}

\author{
Elly Rahayu \\ Program Studi Sistem Informasi, STMIK Royal, Kisaran \\ e-mai: ellyrahayu68@gmail.com
}

\begin{abstract}
This study is purpose to examine the influence of location, completeness of products and services to consumer purchasing decisions at Swalayan Imam Market. The population of this study are consumers who have been shopping at Imam Market Kisaran. The sample of this study is the consumers who shop at Imam Market within the last 3 months The technique sampling used is accidental sampling method. Best of the $t$ test (partial test) that have been done, Service dan Location which have influence to consumer buying decition on Imam Market Kisaran and product completeness has no effect to consumer buying decision on Imam Market Kisaran
\end{abstract}

Keywords: Location, Product Completeness, Purchasing Decision Service, Consumer

\begin{abstract}
Abstrak: Penelitian ini bertujuan untuk bertujuan untuk menguji pengaruh lokasi, kelengkapan produk dan pelayanan terhadap keputusan pembelian konsumen pada Swalayan Imam Market. Populasi dari penelitian ini adalah sewluruh konsumen yang pernah berbelanja di Imam Market Kisaran. Sampel penelitian ini adalah konsumen yang berbelanja di Imam Market dalam kurun waktu 3 bulan terakhir Tehnik pengambilan sampel dilakukan dengan metods accidental sampling. Dari uji t (uji parsial) hanya lokasi dan pelayanan yang berpengaruh terhadap keputusan pembelian konsumen pada Imam Market Kisaran, sementara kelengkapan produk tidak berpengaruh terhadap keputusan pembelian konsumen pada Imam Market Kisaran
\end{abstract}

Kata kunci: Lokasi, Kelengkapan Produk, Pelayanan Keputusan Pembelian, Konsumen

\section{PENDAHULUAN}

$\begin{array}{crr}\text { Strategi } & \text { pemasaran yang } \\ \text { dilakukan oleh produsen sangat }\end{array}$ mempengaruhi konsumen untuk membuat keputusan pembelian produk atau jasa yang ditawarkan. Menurut Kotler (2009) keputusan membeli yaitu: "beberapa tahapan yang dilakukan oleh konsumen sebelum melakukan keputusan pembelian suatu produk". Menurut Setiadi (2010) perilaku membeli mengandung makna yakni kegiatan-kegiatan individu secara langsung terlibat dalam pertukaran uang dengan barang dan jasa serta dalam proses pengambilan keputusan yang menentukan kegiatan tersebut. Menurut Swastha dan Handoko (2011) terdapat lima peran individu dalam sebuah keputusan membeli, yaitu: (1) Pengambilan inisiatif (inisiator): individu yang mempunyai inisiatif pembelian barang tertentu atau 
Available online at http://jurnal.goretanpena.com/index.php/JSSR

yang mempunyai kebutuhan atau keinginan tetapi tidak punya kewenangan untuk melakukan sendiri. (2) Orang yang mempengaruhi (influencer): individu yang mem-pengaruhi keputusan untuk membeli baik secara sengaja maupun tidak sengaja, (3) Pembuatan Keputusan (decider): individu yang memutuskan apakah akan membeli atau tidak, apa yang akan dibeli, bagaimana membelinya, kapan dan dimana membelinya, (4) Pembeli (buyer): individu yang melakukan pembelian yang sebenarnya, (5) Pemakai (user): individu yang menikmati atau memakai produk atau jasa yang dibeli. Penting bagi sebuah perusahaan untuk mengenal peranan ini, karena sangat bermanfaat untuk merancang strategi pemasaran yang akan diterapkan. Sumarni (2010) mengatakan setiap keputusan pembelian mempunyai struktur sebanyak tujuh komponen. Komponen-komponen tersebut antara lain: (a) Keputusan tentang jenis produk; (b) Keputusan tentang bentuk produk; (c) Keputusan tentang merek; (d) Keputusan tentang penjualan; (e) Keputuasan tentang jumlah produk; (f) Keputusan tentang waktu pembelian; (g) Keputusan tentang cara pembayaran.

Selain faktor-faktor tersebut diatas, lokasi juga menjadi faktor yang turut dipertimbangkan oleh konsumen. Hasil penelitian Litsyawati (2017) menyatakan bahwa lokasi berpengaruh terhadap keputusan beli konsumen sementara kelengkapan produk, kualitas produk dan promosi tidak berpengaruh terhadap keputusan pembelian konsumen.

Sementara hasil penelitian Hafidzi (2013) menyatakan bahwa kelengkapan produk dan pelayanan secara simultan berpengaruh terhadap keputusan pembelian konsumen; semakin lengkap produknya dan semakin baik pelayanan yang dibrikan maka semakin tinggi tingkat keputusan pembelian.

Dewasa ini bisnis ritel cukup berkembang pesat, tidak hanya merambah kota-kota besar, di tingkat kabupaten dan kecamatanpun dari hari ke hari jumlahnya terus bertambah, termasuk bisnis ritail di Kota Kisaran kabupaten Asahan.

Konsep baru dunia ritail dapat menarik perhatian konsumen karena menawarkan sesuatu yang baru yang dapat menimbulkan rasa senang dalam berbelanja. Kelebihan-kelebihan itulah yang membuat konsep baru ini sangat dipertimbangkan oleh konsumen sebagai tempat tujuan berbelanja menggeser pasar-pasar tradisional.

Menurut Kotler (2009) Ada beberapa jenis organisasi retail yaitu swalayan, toko khusus, toko serba ada, pasar swalayan, toko kenyamanan (convenience) dan pengecer potongan harga, swapilih kota Kisaran yang merupakan ibu kota kabupaten Asahan menjadi salah satu kota tujuan belanja bagi masyarakat kabupaten Asahan dan sekitarnya. Terdapat banyak usaha ritail di Kisaran diantaranya Swalayan Imam Market, Atlanta Market, Alfamart, Indomaret, Alfa Midi, dan Irian. Berbelanja di swalayan saat ini menjadi gaya hidup masyarakat perkotaan, termasuk masyarakat di Kota Kisaran dan sekitarnya.

Swalayan Imam Market yang terletak di jalan Hos Cokroaminoto Kisaran merupakan salah satu swalayan yang banyak diminati oleh konsumen.. Jika ditinjau dari letaknya, maka swalayan Imam Market berada di pintu gerbang kota Kisaran sehingga jelas dan mudah dijangkau oleh konsumen, namun jika ditinjau dari fasilitas yang disediakan, Imam Market tidak memiliki area parkir yang memadai, meskipun demikian, hasil interview yang dilakukan kepada pemiliknya, \pm 500 konsumen setiap bulannya berbelanja di swalayan tersebut.

Kotler (2009) menyatakan bahwa keputusan membeli yaitu: "beberapa tahapan yang dilakukan oleh konsumen sebelum melakukan keputusan pembelian suatu produk. Setiadi (2010) perilaku membeli mengandung makna yakni kegiatan-kegiatan individu secara 
Available online at http://jurnal.goretanpena.com/index.php/JSSR

langsung terlibat dalam pertukaran uang dengan barang dan jasa serta dalam proses pengambilan keputusan yang menentukan kegiatan tersebut.

Keputusan pembelian menurut Tjiptono (2008) sebuah proses dimana konsumen mengenal masalahnya, mencari informasi mengenai produk atau merek tertentu dan mengevaluasi seberapa baik masing-masing alternatif tersebut dapat memecahkan masalahnya, yang kemudian mengarah kepada keputusan pembelian.

Menurut Kotler dan Armstrong (2009) keputusan pembelian konsumen dipengaruhi oleh empat faktor, yaitu: (1) Faktor Budaya; Budaya, Sub budaya, kelas sosial sangat penting bagi prilaku pembelian; (2) Faktor Sosial; Prilaku pembelian konsumen juga dipengaruhi faktor sosial diantaranya kelompok acuan, keluarga, peran dan status, (3) Faktor pribadi; Keputusan pembelian juga dapat dipengaruhi oleh karakterisitik pribadi diantaranya usia dan tahap siklus hidup, pekerjaan, keadaan ekonomi, gaya hidup, serta kepribadian dan konsep-diri pembeli; (4) Faktor Psiklogis; faktor yang dapat mempengaruhi keputusan pembelian konsumen adalah faktor psikologis seperti motivasi, persepsi, pembelajaran, keyakinan dan sikap.

Lokasi merupakan struktur fisik dari sebuah usaha yang merupakan komponen utama yang terlihat dalam membentuk kesan sebuah usaha yang dilakukan perusahaan dalam melakukan penempatan usahanya dan kegiatan dalam menyediakan saluran pelayanan yang dibutuhkan oleh konsumen (Utami, 2012) Menurut Kotler dan Amstrong (2012) lokasi adalah kegiatan perusahaan yang membuat produk tersedia bagi sasaran. Sementara Lupiyoadi (2006) menyatakan bahwa lokasi merupakan keputusan yang dibuat perusahaan berkaitan dengan dimana operasi dan stafnya akan di tempatkan.

Faktor-faktor yang perlu dipertimbangkan dengan cermat dalam pemilihan lokasi adalah sebagai berikut:
(1) Aksesibilitas yaitu kemudahan untuk dijangkau; (2) Visibilitas yaitu kemudahan untuk dilihat; (3) Lalu lintas; (4) Tempat parkir yang luas dan aman; (5) Ekspansi yaitu tersedianya tempat yang luas untuk perluasan di kemudian hari; (6) Lingkungan sekitar; (7) Persaingan; (8) Peraturan pemerintah.

Kelengkapan produk adalah kelengkapan produk yang menyangkut kedalaman, luas, dan kualitas produk yang ditawarkan juga ketersediaan produk tersebut setiap saat ditoko (Utami, 2012).Penyediaan kelengkapan produk (product assortment) yang baik tidak hanya akan menarik minat tetapi dapat mempengaruhi keputusan konsumen untuk berbelanja. Keragaman produk merupakan kumpulan seluruh produk dan barang yang ditawarkan penjual tertentu kepada pembeli (Kotler, 2007). Hubungan antara keragaman produk dan perilaku konsumen dalam melakukan keputusan tercantum dalam belanja barang.

Raharjani (2005), mengemukakan variabel kelengkapan produk meliputi keragaman barang yang dijual di pasar swalayan dan ketersediaan barang-barang tersebut di pasar swalayan. Indikator dari kelengkapan produk, yaitu: keragaman produk yang dijual, variasi produk yang dijual, ketersediaan produk yang dijual dan macam merek yang tersedia. Faktorfaktor yang dipertimbangkan oleh suatu toko atau department store dalam memilih produk yang dijualnya yaitu: variety, width or breath, depth, consistency dan balance:

a. Variety (variasi) Kelengkapan produk yang dijual dapat mempengaruhi pertimbangan konsumen dalam memilih suatu toko atau department store.

b. Width (lebar) Tersedianya produkproduk pelengkap dari produk utama yang ditawarkan. Contohnya pada toko roti juga menyediakan berbagai macam minuman. 
Available online at http://jurnal.goretanpena.com/index.php/JSSR

c. Depth (Panjang) Merupakan macam dan jenis karakteristik dari suatu produk. Misalnya baju yang dijual di Department Store tidak hanya dari 1 merek saja seperti crocodile tetapi juga tersedia merek-merek lainnya.

Pelayanan menjadi faktor yang dipertimbangkan konsumen dalam membuat keputusan pembelian. Pelayanan yang maksimal tidak hanya membuat konsumen merasa nyaman tetapi juga bisa mendorong konsumen untuk kembali lagi. Moenir (2010) mengatakan bahwa pelayanan adalah kegiatan yang dilakukan oleh seseorang atau sekelompok orang dengan landasan faktor materi melalui sistem, prosedur dan metode tertentu dalam rangka usaha memenuhi kepentingan orang lain sesuai dengan haknya. Kotler (2009) Pelayanan adalah aktivitas atau hasil yang dapat ditawarkan oleh sebuah lembaga kepada pihak lain yang biasanya tidak kasat mata, dan hasilnya tidak dapat dimiliki oleh pihak lain tersebut.

\section{METODE}

Populasi pada penelitian ini adalah konsumen yang berbelanja di swalayan Imam Market dimana rata-rata jumlah konsumen \pm 300 orang perhari (Manajemen Imam Market, 2017). Jumlah sampel yang ditetapkan sebanyak 75 orang. Banyaknya sampel ditentukan dengan menggunakan rumus Slovin. Tehnik pengambilan sampel dilakukan dengan Accidental sampling, jadi setiap orang yang ditemui yang pernah berbelanja di Swalayan Imam Market dapat dijadikan sampel penelitian

Variabel pada penelitian ini terdiri dari variabel bebas (dependent variable) dan varibel terikat (independent variable). Variabel bebas pada penelitian ini yaitu: (1) Lokasi, (2) Kelengkapan Produk dan (3) Pelayanan) dan Keputusan pembelian sebagai variabel terikat

Variabel dalam penelitian ini, baik variabel bebas dan variabel penelitian dijabarkan dalam 24 pernyataan. Skala pengukuran yang digunakan untuk menilai setiap item pernyataan adalah skala likert dengan 5 alternatif pilihan yaitu: (1) Sangat tidak Setuju (STS), (2) Tidak Setuju (TS), (3) Tidak tau (TT), (4) Setuju (S) dan (5) Sangat Setuju (SS).

Metode analisis data yang digunakan adalah Regresi Linier Berganda yang digunakan untuk menguji pengaruh variabel bebas terhadap variabel terikat. Metode analisis data digunakan dengan bantuan software SPSS versi 17 .

\section{HASIL DAN PEMBAHASAN}

\section{Pengujian Validitas dan Reliabilitas}

Hasil pengujian validitas dan reliabilitas tertuang dalam tabel 1 .

Tabel 1. Hasil Uji Validitas

\begin{tabular}{lccc}
\hline \multicolumn{1}{c}{ Variabel } & $\begin{array}{c}\mathrm{R} \\
\text { tabel }\end{array}$ & $\begin{array}{c}\mathrm{R} \\
\text { hitung }\end{array}$ & Ket \\
\hline Lokasi (X1) & 0,224 & 0,916 & Valid \\
\hline $\begin{array}{l}\text { Kelengkapan } \\
\text { Peoduk (X2) }\end{array}$ & 0,224 & 0,710 & Valid \\
\hline $\begin{array}{l}\text { Pelayanan } \\
\text { (X3) }\end{array}$ & 0,224 & 0,879 & Valid \\
\hline
\end{tabular}

Tabel 2. Hasil Uji Reliabilitas

\begin{tabular}{lcc}
\hline \multicolumn{1}{c}{ Variabel } & $\begin{array}{c}\text { Cronbach } \\
\text { Alpha }\end{array}$ & Ket \\
\hline Lokasi (X1) & 0.944 & Reliabel \\
\hline $\begin{array}{l}\text { Kelengkapan } \\
\text { Peoduk (X2) }\end{array}$ & 0,860 & Reliabel \\
\hline $\begin{array}{l}\text { Pelayanan } \\
(X 3)\end{array}$ & 0,885 & Reliabel \\
\hline
\end{tabular}

Uji R Square (R2) dilakukan untuk memprediksi seberapa besar kontribusi pengaruh variabel bebas terhadap variabel terikatnya.

Nilai Adjusted R Squer sebesar 0,648 artinya $68,40 \%$ keputusan pembelian konsumen dipengaruhi oleh variabel bebas (Lokasi, Kelebgkapan Produk dan pelayanan) sisanya sebesar 
Available online at http://jurnal.goretanpena.com/index.php/JSSR

$32,60 \%$ dipengaruhi faktor lain yang tidak diteliti.

Uji t merupakan pengujian untuk menunjukkan signifikansi pengaruh secara individu variabel bebas terhadap variabel terikat.

Dari tabel 4 analisis regresi linier berganda dapat dirumuskan dalam persamaan berikut:

$Y=0,321 X_{1}-0,382 X_{2}+0,841 X_{3}+e$

Persamaan regresi diatas dapat dijelaskan sebagai berikut:

1. Lokasi $\left(X_{1}\right)$. Nilai $t$ hitung diperoleh sebesar 2,581 > dari t tabel 1,666, koefisien regresi sebesar 0,321 dengan taraf signifikansi 0,12> dari 0,05. Artinya Lokasi berpengaruh tidak signifikan terhadap keputusan pembelian konsumen pada Imam Market

2. Kelengkapan Produk $\left(\mathrm{X}_{2}\right)$. Nilai $\mathrm{t}$ hitung sebesar $-2,977<$ dari $t$ tabel sebesar 1,666 dan koefisien regresi sebesar $-3,82$ pada taraf signi-fikansi $0,04<$ dari 0,05. Artinya kelengkapan produk tidak ber-pengaruh signifikan terhadap keputusan pembelian konsumen

3. Pelayanan $\left(X_{3}\right)$. Nilai t hitung sebesar $7,355>$ dari $t$ tabel 1,666 dan nilai koefisien regresi sebesar 0,841 dengan taraf signifikansi sebesar $0,00<$ dari 0,05. Dengan demikian dapat disimpulkan bahwa pelayanan berpengaruh signifikan terhadap keputusan pembelian konsumen

\section{Pembahasan}

Variabel Lokasi secara parsial berpengaruh tidak signifikan terhadap keputusan pembelian konsumen pada Imam Market Kisaran. Hal ini ditunjukkan dengan nilai t hitung sebesar 2,582 > dari t tabel dengan nilai 1,666 dengan taraf signifikansi 0,12> dari 0,05. Dengan demikian hipotesis diterima

Variabel kelengkapan produk secara parsial tidak berpengaruh signifikan terhadap keputusan pembelin konsumen pada Imam Market Kisaran. Hal ini ditunjukkan oleh nilai $\mathrm{t}$ hitung sebesar $-2,997<$ dari t tabel sebesar 1,666 dengan taraf signifikansi sebesar 0,04< dari 0,05. Dengan demikian hipotesis ditolak

Variabel Pelayanan secara parsial berpengaruh terhadap kepu-tusan pembelian konsumen pada Imam Market Kisaran. Hal ini ditunjuk dengan perolehan nilai $\mathrm{t}$ hitung sebesar 7,355> dari t tabel pada taraf signifikansi $0,00<$ dari 0,05. Dengan demikian hipotesis diterima

Tabel 3. Hasil Uji Koefisien Determinasi

\begin{tabular}{ccccc}
\hline Model & $\mathrm{R}$ & R Square & $\begin{array}{c}\text { Adjusted R } \\
\text { Square }\end{array}$ & $\begin{array}{c}\text { Std. Error of } \\
\text { the Estimate }\end{array}$ \\
\hline 1 &, $834^{\mathrm{a}}$ &, 696 &, 684 & 2,465 \\
\hline
\end{tabular}

Tabel 4. Hasil Uji t

\begin{tabular}{|c|c|c|c|c|c|}
\hline \multirow[t]{2}{*}{ Variabel } & \multicolumn{2}{|c|}{$\begin{array}{c}\text { Unstandardized } \\
\text { Coefficients }\end{array}$} & \multirow{2}{*}{$\begin{array}{c}\begin{array}{c}\text { Standardized } \\
\text { Coefficients }\end{array} \\
\text { Beta }\end{array}$} & \multirow[t]{2}{*}{$\mathrm{t}$} & \multirow[t]{2}{*}{ Sig. } \\
\hline & B & Std. Error & & & \\
\hline Lokasi & ,321 & ,124 & ,326 & 2,581 & ,012 \\
\hline Kelengkapan Produk &,- 382 & ,128 &,- 357 & $-2,977$ & ,004 \\
\hline Pelayanan & 841 & ,114 & 823 & 7,355 & 000 \\
\hline
\end{tabular}


Available online at http://jurnal.goretanpena.com/index.php/JSSR

\section{SIMPULAN}

Berdasarkan beberapa pengu-jian diatas maka dapat disimpulkan sebagai berikut:

1. Lokasi secara parsial berpengaruh terhadap keputusan pembelian konsumen dengan nilai $\mathrm{t}$ hitung $2,582>$ dari t tabel 1,666
2. Kelengkapan Produk tidak berpengaruh terhadap keputusan pembelian konsumen, hal ini terlihat dari nilai $\mathrm{t}$ hitung $-2,997<$ dari $\mathrm{t}$ tabel 1,666

3. Pelayanan berpengaruh signifikan terhadap keputusan pembelian konsumen. Hal ini terlihat pada nilai t hitung sebesar 7,355 > dari t tabel 1,666

\section{DAFTAR PUSTAKA}

Alreza \& Hafidzi. 2013. Pengaruh Kelengkapan Produk dan Pelayanan terhadap Keputusan Pembelian Pada Mini Market Alfamart. Jurnal EMBA.

Kotler, Philip dan Keller. 2007. Manajemen Pemasaran. Jakarta: PT. Indeks

Listyawati, I.H. 2017. Pengaruh Lokasi, Kelengkapan Produk, Kualitas Produk Dan Promosi Terhadap Keputusan Beli Konsumen Di Pamella Empat Yogyakarta. JBME. 4(2).

Lupiyoadi, H. 2006. Manajemen Pemasaran Jasa. Jakarta: Salemba Empat

Moenir. A.S. 2010. Manajemen Pelayanan Umum di Indonesia. Jakarta : Bumi Aksara

Raharjani, J. 2005. Analisis Faktor-faktor yang Mempengaruhi Keputusan Pemilihan Pasar Swalayan
Sebagai Tempat Berbelanja (Studi Kasus Pada Pasar Swalayan di Kawasan Seputar Simpang Lima Semarang). Jurnal Studi Manajemen \& Organisasi. II(1): $1-15$.

Setiadi, N.J. 2010. Perilaku Konsumen. Jakarta: Kencana

Sugiyono. 2014. Metode Penelitian Pendidikan Pendekatan Kuantitatif, Kualitatif, dan $R \& D$. Bandung: Alfabeta

Sumarni, M. \& Soeprihanto, J. 2010. Pengantar Bisnis (dasar-dasar ekonomi perusahaan. Yogyakarta: Liberty

Swastha, B. 2009. Manajemen Penjualan Yogyakarta: BPFE

Utami, C. W. 2012, Manajemen Ritel Strategi Dan Implementasi Ritel Modern, Jakarta: Salemba Empat.

Tjiptono, F. 2008. Strategi Pemasaran. Yogyakarta: Andi 